\title{
Synchronization of rumen degradable protein with non-fiber carbohydrate on microbial protein synthesis and dairy ration digestibility
}

\author{
Annisa Rosmalia1 (iD, Idat Galih Permana² (iD and Despal Despal² (iD
}

1. Nutrition and Feed Science Study Program, Faculty of Animal Science, IPB University, Bogor 16680, West Java, Indonesia; 2. Department of Animal Nutrition and Feed Technology, Faculty of Animal Science, IPB University, Bogor 16680, West Java, Indonesia.

Corresponding author: Idat Galih Permana, e-mail: permana@apps.ipb.ac.id

Co-authors: AR: rosmalia_annisa@apps.ipb.ac.id, DD: despal@apps.ipb.ac.id

Received: 31-08-2021, Accepted: 07-01-2022, Published online: 05-02-2022

doi: www.doi.org/10.14202/vetworld.2022.252-261 How to cite this article: Rosmalia A, Permana IG, Despal D (2022) Synchronization of rumen degradable protein with non-fiber carbohydrate on microbial protein synthesis and dairy ration digestibility, Veterinary World, 15(2): 252-261.

\begin{abstract}
Background and Aim: Dairy ration formulations should consider the synchronization of the rumen degradable protein (RDP) to rumen undegradable protein (RUP) ratio (RDPR) with non-fiber carbohydrate (NFC) to achieve optimum microbial protein synthesis (MPS), reduce feed costs, and reduce $\mathrm{N}$ excretion to the environment. This study aimed to investigate the effect of RDPR and NFC synchronization on in vitro digestibility, fermentability, and MPS.

Materials and Methods: The experiment used a $3 \times 3$ factorial randomized block design with four replications. The first factor was RDPR (RDPR1 $=50: 50 ; \mathrm{RDPR} 2=55: 45 ; \mathrm{RDPR} 3=60: 40)$ and the second factor was NFC levels $(\mathrm{NFC} 1=30 \%$, $\mathrm{NFC} 2=35 \%, \mathrm{NFC} 3=40 \%$ ). The experimental diets were evaluated using a two-stage in vitro method. The examined parameters included rumen $\mathrm{pH}, \mathrm{NH}_{3}$ concentration, total volatile fatty acid (VFA) concentration, the molar proportion of VFAs, rumen microbes (protozoa and total bacteria population), and MPS. Data were analyzed using ANOVA, followed by the Duncan test.

Results: The results show that neither RDPR nor NFC affected rumen $\mathrm{pH}, \mathrm{NH}_{3}$, total VFA, and the rumen microbe population. The interaction between RDPR and NFC affected the molar proportion of acetate, iso-butyrate, and n-valerate. The combination of RDPR1 and NFC1 produced a lower molar proportion of acetate $(49.73 \%)$ than the other treatment combinations $(>54 \%)$. The acetate to propionate ratio was influenced by the NFC levels, in which NFC2 and NFC3 produced the highest ratio $(p<0.05)$. MPS was affected by RDPR and NFC, but not by their interaction. Treatments NFC2 and RDPR3 produced the highest MPS. NFC affected the dry matter and organic matter digestibility (DMD and OMD), with treatment NFC3 resulting in the highest DMD and OMD.
\end{abstract}

Conclusion: The combination of a 60:40 RDPR with 35\% NFC resulted in the best synchronization of protein and energy available for MPS and digestion activity in the rumen.

Keywords: dairy ration digestibility, microbial protein synthesis, rumen degradable protein, rumen undegradable protein, synchronization.

\section{Introduction}

Ruminant protein requirements can be divided into rumen degradable protein (RDP) and rumen undegradable protein (RUP). RDP is required for microbial protein synthesis (MPS) as a source of nitrogen $(\mathrm{N})$ which plays a role in supplying protein to dairy cattle [1]. In addition to protein and nutrient sufficiency, dairy ration formulations should consider the RDP to RUP ratio (RDPR) for optimal MPS. Rumen microbes need the RDPR as a source of $\mathrm{N}$ and energy as a source of carbon (C); both $\mathrm{N}$ and $\mathrm{C}$ should be available in the right proportion to improve MPS efficiency [2,3]. Therefore, degradable protein

Copyright: Rosmalia, et al. Open Access. This article is distributed under the terms of the Creative Commons Attribution 4.0 International License (http://creativecommons.org/licenses/ by/4.0/), which permits unrestricted use, distribution, and reproduction in any medium, provided you give appropriate credit to the original author(s) and the source, provide a link to the Creative Commons license, and indicate if changes were made. The Creative Commons Public Domain Dedication waiver (http:// creativecommons.org/publicdomain/zero/1.0/) applies to the data made available in this article, unless otherwise stated. and fermentable carbohydrates should be provided. Non-fiber carbohydrate (NFC) provides readily available carbohydrate (fermentable) that contains sugars, starch, fructans, pectin substance, galactans, and $\beta$-glucans [4]. NFC is calculated using the following formula: $\mathrm{NFC}=100$ - neutral detergent fiber - crude protein - ether extract - ash. The difference between NFC and non-structural carbohydrate is the neutral detergent soluble fiber (pectin, galactans, and $\beta$-glucans), which is included in NFC [4,5]. NFC can be provided in rations at $30-45 \%$ of dry matter (DM) [6].

The synchronization between RDPR and NFC is closely related to ruminal fermentation, which requires an optimum level. The optimum RDPR and energy levels are beneficial to milk protein production due to the increase of MPS [7]. The previous studies have reported that the NFC source and RDP synchronization affect rumen fermentation, microbial growth, lactation performance, and blood parameters in dairy cows $[6,8]$. High NFC diets synchronized with RDP reduce $\mathrm{N}$ losses [9]. On the other hand, 
unsynchronized RDPR and NFC lead to feed inefficiency, high feed costs, and high excess $\mathrm{N}$ pollution to the environment [10]. The National Research Council (NRC) [11] recommends that the optimal RDPR for dairy cows is 60:40. A previous study reported that feeding dairy cows with RDPR of 65:35 led to better milk production than RDPR of 60:40 [12].

Conversely, dairy rations with RDPR below the NRC recommendation [11] decrease milk yield, milk fat, and milk protein due to insufficient RDP available for rumen microbial growth [13]. Low RDPR depresses DM intake and milk production [14]. Moreover, RDPR of 63:37 is also more efficient in early lactating dairy cows, providing optimal protein for milk production and minimum urinary $\mathrm{N}$ excretion [15]. Dairy rations containing high NFC increase ammonia $\mathrm{N}$ utilization and MPS [16]. In addition, supplying energy as high NFC improves protein metabolism in the body, impacting milk production and quality, especially milk protein [17]. Feed efficiency and $\mathrm{N}$ conversion are also improved with a high NFC $\operatorname{diet}[18]$.

Information concerning the RDPR and NFC in dairy feedstuffs has mainly been investigated in developed countries, which use different feedstuffs than the tropical dairy ration [19-21]. Moreover, synchronization index assessments conducted in a temperate region may not be suitable for application to tropical conditions. Thus, the objective of this study was to evaluate the effects of tropical dairy rations based on RDPR and NFC synchronization on digestibility, fermentability, and MPS using an in vitro method.

\section{Materials and Methods}

\section{Ethical approval}

The cannulation surgery of animal was carried out by a licensed veterinarian and followed the protocol handling and care of animal according to the IPB University Animal Ethics Committee.

\section{Study period and location}

This study was conducted from January to April 2021 at the Laboratory of Dairy Nutrition, Faculty of Animal Science, IPB University.

\section{Experimental diet}

The experiment used a $3 \times 3$ factorial randomized block design; the first factor was RDPR $(\mathrm{RDPR} 1=50: 50 ; \quad \mathrm{RDPR} 2=55: 45 ; \quad \mathrm{RDPR} 3=60: 40)$ and the second factor was NFC levels $(\mathrm{NFCl}=30 \%$; $\mathrm{NFC} 2=35 \%$; $\mathrm{NFC} 3=40 \%$ ). The rations contained $40 \%$ forage and $60 \%$ concentrate (DM basis). The experimental dairy rations were formulated based on the requirements and energy-protein balances from the NRC [11]. The RDPR of the ration was calculated using a local database generated from a previous study in our laboratory, whereas NFC was calculated according to the methodology of Mertens [5]. The feed ingredients and chemical composition of the rations are shown in Table-1 [22].

\section{In vitro procedure and sample measurement}

This study used the two-stage method procedure of Tilley and Terry [23]. Rumen liquor, as an inoculant source, was collected from ruminal fistulated Frisian Holstein $(\mathrm{BW} \pm 510 \mathrm{~kg}$ ) before morning feeding. The rumen liquor was filtered using two layers

Table-1: The feed ingredients and chemical composition of dairy rations ${ }^{1}$.

\begin{tabular}{|c|c|c|c|c|c|c|c|c|c|}
\hline \multirow[t]{2}{*}{ Items } & \multicolumn{3}{|c|}{ NFC1 } & \multicolumn{3}{|c|}{ NFC2 } & \multicolumn{3}{|c|}{ NFC3 } \\
\hline & RDPR1 & RDPR2 & RDPR3 & RDPR1 & RDPR2 & RDPR3 & RDPR1 & RDPR2 & RDPR3 \\
\hline \multicolumn{10}{|c|}{ Ingredients, $\%$ of diet DM } \\
\hline Napier grass & 40.00 & 40.00 & 40.00 & 40.00 & 40.00 & 40.00 & 40.00 & 40.00 & 40.00 \\
\hline Corn & 11.55 & 10.50 & 10.10 & 10.00 & 10.00 & 10.00 & 11.85 & 11.90 & 11.40 \\
\hline Rice bran & 6.80 & 9.00 & 8.00 & 4.39 & 4.20 & 3.50 & 0.00 & 0.00 & 0.00 \\
\hline Pollard & 6.65 & 6.20 & 7.25 & 1.50 & 1.10 & 1.50 & 0.00 & 0.00 & 1.00 \\
\hline Cassava meal & 11.50 & 11.50 & 11.95 & 22.00 & 22.00 & 22.25 & 32.60 & 31.60 & 31.40 \\
\hline Soybean meal & 1.00 & 5.40 & 10.60 & 2.36 & 8.75 & 13.25 & 1.00 & 8.00 & 12.20 \\
\hline Corn gluten meal & 10.00 & 5.00 & 0.20 & 9.80 & 4.00 & 0.20 & 12.00 & 6.00 & 2.00 \\
\hline Copra meal & 3.00 & 6.00 & 7.70 & 4.00 & 4.00 & 4.30 & 0.00 & 0.50 & 0.00 \\
\hline Coffee husk & 7.50 & 4.40 & 2.20 & 3.95 & 3.95 & 3.00 & 0.55 & 0.00 & 0.00 \\
\hline Calcium carbonate & 1.00 & 1.00 & 1.00 & 1.00 & 1.00 & 1.00 & 1.00 & 1.00 & 1.00 \\
\hline Dicalcium phosphate & 0.50 & 0.50 & 0.50 & 0.50 & 0.50 & 0.50 & 0.50 & 0.50 & 0.50 \\
\hline $\mathrm{NaCl}$ & 0.50 & 0.50 & 0.50 & 0.50 & 0.50 & 0.50 & 0.50 & 0.50 & 0.50 \\
\hline \multicolumn{10}{|l|}{ Chemical composition } \\
\hline DM, \% & 92.43 & 92.70 & 92.47 & 92.19 & 91.85 & 90.63 & 90.04 & 90.18 & 90.37 \\
\hline Ash, \% DM & 9.08 & 9.84 & 9.87 & 8.86 & 9.43 & 9.80 & 7.38 & 7.65 & 8.08 \\
\hline EE, \% DM & 1.66 & 1.72 & 2.18 & 1.88 & 1.65 & 1.64 & 0.88 & 0.80 & 0.87 \\
\hline$C P, \% D M$ & 15.83 & 16.10 & 15.40 & 16.43 & 15.98 & 15.97 & 16.42 & 15.89 & 15.48 \\
\hline CF, \% DM & 17.43 & 16.59 & 15.96 & 15.80 & 15.90 & 15.74 & 13.72 & 14.71 & 13.50 \\
\hline NFE, \% DM & 56.00 & 55.74 & 56.58 & 57.03 & 57.03 & 56.84 & 61.60 & 60.95 & 62.07 \\
\hline $\mathrm{TDN}^{2}, \%$ & 64.42 & 64.88 & 65.73 & 66.83 & 65.88 & 65.73 & 69.39 & 67.81 & 68.71 \\
\hline
\end{tabular}

${ }^{1}$ Experimental dairy rations: NFC1 $=$ NFC 30\%; NFC2 =NFC 35\%; NFC3=NFC 40\%; RDPR1=50:50 RDP: RUP ratio;

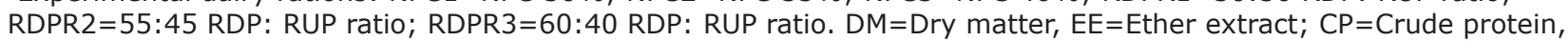
$\mathrm{CF}=$ Crude fiber, $\mathrm{NFE}=$ Nitrogen free extract, $\mathrm{TDN}=$ Total digestible nutrient. ${ }^{2} \mathrm{TDN}=2.79+(1.17 \times \% \mathrm{CP})+(1.74 \times \% \mathrm{EE})-(0.29$ $5 \times \% C F)+(0.81 \times \% N F E)[22]$ 
of cheesecloth. A $0.5 \mathrm{~g}$ sample was placed in a fermenter tube, to which $40 \mathrm{~mL}$ pre-warmed McDougall buffer solution and $10 \mathrm{~mL}$ rumen liquor was added. The tube was aerated with $\mathrm{CO}_{2}$ to generate anaerobic conditions, capped with a ventilated rubber stopper, and placed in a shaker water bath at $39^{\circ} \mathrm{C}$ for $48 \mathrm{~h}$.

After $4 \mathrm{~h}$ of incubation, $0.5 \mathrm{~mL}$ and $1 \mathrm{~mL}$ of fermentation liquid were separated for total bacterial and protozoa counts, respectively. Two drops of $\mathrm{HgCl}_{2}$ were added to the tube to halt fermentation activity. The tube was centrifuged at $1409 \mathrm{x}$ g for $15 \mathrm{~min}$. The supernatant was collected and frozen, which was later used to determine $\mathrm{NH}_{3}$ concentration, total volatile fatty acid (VFA) concentration, and the molar proportion of VFAs.

For digestibility measurements, a similar incubation procedure was conducted. After $48 \mathrm{~h}$ of in vitro rumen incubation, two drops of $\mathrm{HgCl}_{2}$ solution were added to halt the microbial activity. Then, the sample residue obtained after centrifugation was combined with $50 \mathrm{~mL}$ of $0.2 \%$ pepsin- $\mathrm{HCl}$ solution and incubated at $39^{\circ} \mathrm{C}$ for $48 \mathrm{~h}$. After $48 \mathrm{~h}$ of pepsin- $\mathrm{HCl}$ incubation, the samples were filtered using a pre-determined weight of Whatman filter paper No. 41 using a vacuum pump. Afterward, the paper was dried to determine the DM residue and incinerated to determine the ash residue.

Rumen $\mathrm{pH}$ was measured using a $\mathrm{pH}$ meter (Hanna Instruments, HI98191, Romania). The supernatant was thawed at room temperature $\left(25^{\circ} \mathrm{C}\right)$ before analyzing $\mathrm{NH}_{3}$, total VFAs, and MPS. The $\mathrm{NH}_{3}$ concentration was determined using the Conway microdiffusion method, whereas the total VFA concentration was determined using the steam distillation method; both methods were similar to those used by Riestanti et al. [24]. Individual VFA (molar proportion) was analyzed using gas chromatography, using a procedure described by Yulistiani et al. [25]. Methane production was estimated from the individual VFA using the formula: $\mathrm{CH}_{4}=0.45 \times$ acetate$0.275 \times$ propionate $+0.40 \times$ butyrate [26]. After coloring using Trypan blue formal saline, rumen protozoa were counted using a microscope (XSZ-107BN binocular biological microscope, BW Optics, China) with $4 \times 10$ magnification. Total rumen bacteria were counted using serial dilution and cultured for $24 \mathrm{~h}$ in BHI media (HiMedia, India). The counting followed the Ogimoto and Imai methods as described byHu et al. [27] and Wahyudi et al. [28].

\section{Statistical analysis}

Data were analyzed by one-way analysis of variance using the statistical analysis system program OnDemand for Academic (SAS Inc., NC, USA). Statistical significance was set at $p<0.05$. Differences between means were compared using Duncan's multiple range test.

\section{Results}

\section{Fermentation characteristics}

The observed fermentation characteristics (rumen $\mathrm{pH}, \mathrm{NH}_{3}$ concentration, and total VFA concentration) are shown in Table-2. There was no interaction between the two factors (RDPR and NFC) and no significant effects of the main factors on rumen $\mathrm{pH}, \mathrm{NH}_{3}$, and total VFA concentration ( $\left.\mathrm{p}>0.05\right)$. The rumen $\mathrm{pH}$ values in this study ranged from 6.92 to 6.97, which was within the normal range (6.0-7.0) according to Poulsen et al. [29]. The $\mathrm{NH}_{3}$ and VFA concentrations also fell within the normal ranges, with values ranging from 7.60 to $8.11 \mathrm{mM}$ and 100.96 to $121.20 \mathrm{mM}$, respectively [30,31].

Individual VFAs consisted of short-chain fatty acids (acetate, propionate, and n-butyrate), branchedchain fatty acids (iso-butyrate and iso-valerate), and n-valerate. The interaction between RDPR and NFC affected the molar proportion of acetate $(\mathrm{p}=0.018)$, but did not affect the molar proportion of propionate $(\mathrm{p}=0.668)$. The NFC2 and NFC3 combinations $(35 \%$ NFC and $40 \%$ NFC, respectively) with RDPR treatment resulted in a high molar proportion of acetate. High NFC levels decreased the molar proportion of n-butyrate $(\mathrm{p}=0.040)$. There was an interaction

Table-2: $\mathrm{pH}, \mathrm{NH}_{3}$, and total VFA concentration of the experimental diet.

\begin{tabular}{llcccc}
\hline Parameters & RDP & \multicolumn{2}{c}{ NFC } & Average 0 SD \\
\cline { 3 - 5 } & & NFC1 & NFC2 & NFC3 & \\
\hline $\mathrm{pH}$ & RDPR1 & 6.98 & 6.95 & 6.92 & $6.95 \pm 0.04$ \\
& RDPR2 & 6.93 & 6.93 & 6.88 & $6.91 \pm 0.05$ \\
& RDRP3 & 6.93 & 6.97 & 6.92 & $6.94 \pm 0.04$ \\
$\mathrm{NH}_{3}(\mathrm{mM})$ & Average \pm SD & $6.95 \pm 0.04$ & $6.95 \pm 0.05$ & $6.91 \pm 0.04$ & $7.68 \pm 2.64$ \\
& RDPR1 & 7.86 & 7.60 & 7.59 & $7.90 \pm 1.91$ \\
& RDPR2 & 7.79 & 7.81 & 8.11 & $7.92 \pm 2.02$ \\
$\mathrm{VFA}$ total $(\mathrm{mM})$ & RDRP3 & 8.09 & 7.56 & 8.09 & \\
& Average \pm SD & $7.91 \pm 2.70$ & $7.66 \pm 2.02$ & $7.93 \pm 1.81$ & $110.96 \pm 20.81$ \\
& RDPR1 & 100.96 & 121.20 & 10.71 & $118.03 \pm 22.70$ \\
& RDPR2 & 130.40 & 114.67 & 109.02 & $115.00 \pm 19.27$ \\
& RDRP3 & 114.75 & 121.02 & $109.65 \pm 22.62$ & \\
\hline
\end{tabular}

NFC=Non-fiber carbohydrate. RDPR=RDP: RUP ratio. NFC1=NFC 30\%; NFC2=NFC 35\%; NFC3=NFC 40\%; RDPR1=50:50 RDP: RUP ratio; RDPR2=55:45 RDP: RUP ratio; RDPR3=60:40 RDP: RUP ratio. VFA=Volatile fatty acids 
between the two factors, both for the molar proportion of iso-butyrate $(p=0.017)$ and $n$-valerate $(p=0.031)$, but no significant difference in the molar proportion of iso-valerate $(p=0.210)$. The acetate to propionate ratio increased with increasing NFC levels $(p=0.020)$. Meanwhile, methane production was affected by both the RDPR and NFC treatments $(\mathrm{p}=0.010$ and $\mathrm{p}=0.002)$. The molar proportion of VFA $(\mathrm{mol} / 100$ $\mathrm{mol}$ ), acetate to propionate ratios, and methane production is detailed in Table-3.

\section{Rumen microbes and MPS}

The rumen microbe population indicates how nutrient degradation occurs in the rumen. The protozoa, total bacteria population, and MPS results are presented in Table-4. Both main factors and their interaction did not significantly affect the protozoa nor the total bacteria population $(\mathrm{p}>0.05)$. MPS was significantly affected by both the NFC and RDPR treatments $(\mathrm{p}=0.049)$, but these two factors did not interact. NFC2 (35\% NFC) produced higher MPS than NFC1 and NFC3. In contrast, RDPR3 (RDPR of 60:40) had higher MPS than RDPR1 and RDPR2.

\section{Dry matter and organic matter digestibility (DMD and OMD)}

DMD and OMD are presented in Table-5, neither of which were affected by the interaction between RDPR and NFC. RDPR did not significantly influence DMD $(p=0.314)$ and OMD $(p=0.359)$, but NFC levels $(p=0.000$ and $p=0.001$ for DMD and OMD respectively). NFC3 produced the highest DMD and OMD, but NFC1 and NFC2 showed similar results. The mean DMD and OMD ranged from 61.46 to $76.22 \%$ and 60.09 to $75.12 \%$, respectively.

\section{Discussion}

\section{Fermentation characteristics}

Rumen $\mathrm{pH}$ describes the rumen condition; it is one of the factors that determine the fermentation process. Suitable $\mathrm{pH}$ conditions will support rumen microbial life, such that fermentation can proceed. This study showed that the rumen $\mathrm{pH}$ value was not affected by increases in RDPR and NFC; similar results were also reported by Pilachai et al. [32] and Wei et al. [18]. This insignificant effect of RDPR and NFC is due to the rumen microbes' utilization of $\mathrm{N}$ and VFAs for synthesis, which does not acidify the

Table-3: Molar proportion of VFA, acetate to propionate ratios, and methane production of experimental diet.

\begin{tabular}{|c|c|c|c|c|c|}
\hline \multirow[t]{2}{*}{ Parameters } & \multirow[t]{2}{*}{ RDPR } & \multicolumn{3}{|c|}{ NFC } & \multirow[t]{2}{*}{ Average \pm SD } \\
\hline & & NFC1 & NFC2 & NFC3 & \\
\hline \multirow[t]{4}{*}{ Acetate (\%) } & RDPR1 & $49.73^{b}$ & $57.34^{a}$ & $59.12^{\mathrm{a}}$ & $53.94 \pm 4.17$ \\
\hline & RDPR2 & $54.21^{\mathrm{ab}}$ & $56.57^{a}$ & $58.61^{a}$ & $57.88 \pm 3.42$ \\
\hline & RDRP3 & $57.87^{a}$ & $59.72^{\mathrm{a}}$ & $57.99^{a}$ & $58.58 \pm 1.85$ \\
\hline & Average \pm SD & $55.40 \pm 5.62$ & $56.47 \pm 2.39$ & $58.53 \pm 1.81$ & \\
\hline \multirow[t]{4}{*}{ Propionate (\%) } & RDPR1 & 20.25 & 18.03 & 18.50 & $18.93 \pm 1.99$ \\
\hline & RDPR2 & 18.71 & 18.09 & 18.39 & $18.40 \pm 1.81$ \\
\hline & RDRP3 & 18.43 & 17.87 & 18.20 & $18.17 \pm 1.79$ \\
\hline & Average $\pm S D$ & $19.13 \pm 1.79$ & $18.00 \pm 2.06$ & $18.36 \pm 1.62$ & \\
\hline \multirow[t]{4}{*}{ n-butyrate (\%) } & RDPR 1 & 13.29 & 11.74 & 11.59 & $12.20 \pm 1.34$ \\
\hline & RDPR2 & 12.62 & 12.54 & 12.11 & $12.42 \pm 0.74$ \\
\hline & RDRP3 & 12.02 & 11.45 & 11.59 & $11.69 \pm 0.79$ \\
\hline & Average $\pm S D$ & $12.64 \pm 1.05^{a}$ & $11.91 \pm 0.98^{\mathrm{b}}$ & $11.76 \pm 0.86^{b}$ & \\
\hline \multirow[t]{4}{*}{ Iso-butyrate (\%) } & RDPR 1 & $5.45^{\mathrm{ab}}$ & $5.10^{\mathrm{ab}}$ & $4.20^{\mathrm{ab}}$ & $5.35 \pm 1.41$ \\
\hline & RDPR2 & $5.90^{\mathrm{a}}$ & $5.89^{a}$ & $2.91^{b}$ & $4.85 \pm 1.53$ \\
\hline & RDRP3 & $4.70^{\mathrm{ab}}$ & $3.56^{\mathrm{ab}}$ & $4.71^{\mathrm{ab}}$ & $3.94 \pm 1.48$ \\
\hline & Average \pm SD & $4.92 \pm 1.35$ & $4.90 \pm 1.97$ & $4.32 \pm 1.30$ & \\
\hline \multirow[t]{4}{*}{ Iso-valerate (\%) } & RDPR1 & 5.69 & 4.79 & 4.56 & $5.01 \pm 1.10$ \\
\hline & RDPR2 & 5.17 & 4.95 & 5.44 & $5.19 \pm 0.53$ \\
\hline & RDRP3 & 4.31 & 5.10 & 5.18 & $4.87 \pm 0.94$ \\
\hline & Average $\pm S D$ & $5.05 \pm 0.99$ & $4.95 \pm 1.01$ & $5.06 \pm 0.67$ & \\
\hline \multirow{4}{*}{ n-valerate $(\%)$} & RDPR1 & $5.59^{\mathrm{a}}$ & $3.00^{\mathrm{b}}$ & $2.03^{b}$ & $3.54 \pm 1.95$ \\
\hline & RDPR2 & $3.40^{\mathrm{ab}}$ & $1.96^{\mathrm{b}}$ & $2.54^{b}$ & $2.63 \pm 1.05$ \\
\hline & RDRP3 & $2.66^{\mathrm{b}}$ & $2.29^{b}$ & $2.32^{\mathrm{b}}$ & $2.42 \pm 0.54$ \\
\hline & Average $\pm S D$ & $3.88 \pm 1.57$ & $2.42 \pm 1.23$ & $2.29 \pm 0.54$ & \\
\hline Acetate to & RDPR1 & 2.47 & 3.24 & 3.24 & $2.98 \pm 0.61$ \\
\hline \multirow[t]{3}{*}{ propionate ratios } & RDPR2 & 2.94 & 3.17 & 3.20 & $3.10 \pm 0.38$ \\
\hline & RDRP3 & 3.16 & 3.38 & 3.21 & $3.25 \pm 0.37$ \\
\hline & Average $\pm S D$ & $2.86 \pm 0.46^{b}$ & $3.26 \pm 0.50^{a}$ & $3.22 \pm 0.34^{a}$ & \\
\hline \multirow[t]{4}{*}{$\mathrm{CH}_{4}(\mathrm{mM})$} & RDPR 1 & 7.73 & 5.41 & 6.54 & $6.56 \pm 1.37^{b}$ \\
\hline & RDPR2 & 7.27 & 6.02 & 7.10 & $6.80 \pm 1.25^{b}$ \\
\hline & RDRP3 & 9.18 & 6.96 & 7.92 & $8.02 \pm 1.44^{a}$ \\
\hline & Average $\pm S D$ & $8.06 \pm 1.16^{a}$ & $6.13 \pm 1.40^{\mathrm{b}}$ & $7.19 \pm 1.22^{\mathrm{a}}$ & \\
\hline
\end{tabular}

Means in the same row and column with different superscripts significantly different $(p<0.05)$. NFC = Non-fiber carbohydrate. RDPR = RDP: RUP ratio. NFC1 = NFC 30\%; NFC2 = NFC 35\%; NFC3 = NFC 40\%; RDPR1 = 50:50 RDP: RUP ratio; RDPR2 = 55:45 RDP: RUP ratio; RDPR3 = 60:40 RDP: RUP ratio 
Table-4: Total bacteria and protozoa population, microbial protein synthesis of experimental diet.

\begin{tabular}{|c|c|c|c|c|c|}
\hline \multirow[t]{2}{*}{ Parameters } & \multirow[t]{2}{*}{ RDPR } & \multicolumn{3}{|c|}{ NFC } & \multirow[t]{2}{*}{ Average $\pm S D$} \\
\hline & & NFC1 & NFC2 & NFC3 & \\
\hline Total bacteria & RDPR1 & 8.17 & 8.20 & 7.99 & $8.12 \pm 0.34$ \\
\hline population & RDPR2 & 7.97 & 8.34 & 8.12 & $8.14 \pm 0.25$ \\
\hline \multirow[t]{2}{*}{$(\log \mathrm{CFU} / \mathrm{ml})$} & RDRP3 & 8.22 & 8.16 & 7.80 & $8.06 \pm 0.37$ \\
\hline & Average $\pm S D$ & $8.12 \pm 0.30$ & $8.23 \pm 0.24$ & $7.97 \pm 0.37$ & \\
\hline Protozoa population & RDPR1 & 6.51 & 6.62 & 6.57 & $6.57 \pm 0.11$ \\
\hline \multirow{3}{*}{$(\log$ cell $/ \mathrm{ml})$} & RDPR2 & 6.59 & 6.59 & 6.64 & $6.60 \pm 0.10$ \\
\hline & RDRP3 & 6.55 & 6.57 & 6.65 & $6.59 \pm 0.12$ \\
\hline & Average $\pm S D$ & $6.55 \pm 0.10$ & $6.60 \pm 0.09$ & $6.62 \pm 0.13$ & \\
\hline \multirow[t]{4}{*}{ MPS (mg/10 ml) } & RDPR 1 & 7.17 & 7.07 & 6.80 & $7.01 \pm 0.83^{\mathrm{ab}}$ \\
\hline & RDPR2 & 6.46 & 7.40 & 6.96 & $6.94 \pm 0.90^{\mathrm{b}}$ \\
\hline & RDRP3 & 7.23 & 8.21 & 7.09 & $7.51 \pm 1.12^{\mathrm{a}}$ \\
\hline & Average $\pm S D$ & $6.95 \pm 0.96^{b}$ & $7.56 \pm 1.12^{\mathrm{a}}$ & $6.95 \pm 0.70^{\mathrm{b}}$ & \\
\hline
\end{tabular}

Means in the same row or column with different superscripts are significantly different $(p<0.05)$. NFC $=$ Non-fiber carbohydrate. RDPR=RDP: RUP ratio. NFC1=NFC 30\%; NFC2=NFC 35\%; NFC3=NFC 40\%; RDPR1=50:50 RDP: RUP ratio; RDPR2=55:45 RDP: RUP ratio; RDPR3=60:40 RDP: RUP ratio. CFU=Colony forming unit; $M P S=$ Microbial protein synthesis

Table-5: Dry matter and organic matter digestibility of the experimental diet.

\begin{tabular}{|c|c|c|c|c|c|}
\hline \multirow[t]{2}{*}{ Parameters } & \multirow[t]{2}{*}{ RDPR } & \multicolumn{3}{|c|}{ NFC } & \multirow[t]{2}{*}{ Average $\pm S D$} \\
\hline & & NFC1 & NFC2 & NFC3 & \\
\hline \multirow[t]{4}{*}{ DMD (\%) } & RDPR1 & 61.46 & 68.00 & 71.73 & $67.07 \pm 8.36$ \\
\hline & RDPR2 & 65.44 & 67.06 & 71.29 & $67.93 \pm 7.29$ \\
\hline & RDRP3 & 65.21 & 68.21 & 76.22 & $69.88 \pm 8.45$ \\
\hline & Average $\pm S D$ & $64.04 \pm 8.00^{\mathrm{b}}$ & $67.76 \pm 6.87^{b}$ & $73.08 \pm 6.53^{\mathrm{a}}$ & \\
\hline OMD & RDPR1 & 60.09 & 67.04 & 70.18 & $65.77 \pm 8.63$ \\
\hline \multirow[t]{3}{*}{ (\%) } & RDPR2 & 64.25 & 65.63 & 69.59 & $66.49 \pm 7.58$ \\
\hline & RDRP3 & 63.59 & 66.96 & 75.12 & $68.56 \pm 8.88$ \\
\hline & Average $\pm S D$ & $62.64 \pm 8.41^{b}$ & $66.54 \pm 7.26^{b}$ & $71.63 \pm 6.91^{a}$ & \\
\hline
\end{tabular}

Means in the same row with different superscripts significantly different $(p<0.05)$. NFC=Non-fiber carbohydrate. RDPR=RDP: RUP ratio. NFC1=NFC 30\%; NFC2=NFC 35\%; NFC3=NFC 40\%; RDPR1=50:50 RDP: RUP ratio; RDPR2=55:45 RDP: RUP ratio; RDPR3=60:40 RDP: RUP ratio. DMD=Dry matter digestibility, OMD=Organic matter digestibility

rumen. The rumen $\mathrm{pH}$ values noted in this study were in the range of 6.92-6.97, indicating that there was no acidosis in the rumen, even at the highest RDPR and NFC levels. A pH of 6.0-7.0 is the ideal rumen $\mathrm{pH}$ to support the growth of rumen microbes and their activity in producing fermentation products such as $\mathrm{NH}_{3}$ and VFAs; under these conditions, the activity and composition of rumen microbes are not affected [29]. This $\mathrm{pH}$ range is also ideal for cellulolytic microbial activity $[33,34]$.

Ammonia $\left(\mathrm{NH}_{3}\right)$ is the main $\mathrm{N}$ source for MPS, and the $\mathrm{NH}_{3}$ concentration describes the amount of $\mathrm{N}$ used by microbes [35]. According to McDonald et al. [30], the optimal $\mathrm{NH}_{3}$ concentration ranges from 85 to $300 \mathrm{mg} / 1$, or equivalent to 4.9 to $17.6 \mathrm{mM}$. The minimum ammonia concentration for microbial protein production is $3.6 \mathrm{mM}$ [36]. In this study, the $\mathrm{NH}_{3}$ concentrations ranged from 7.60 to $8.11 \mathrm{mM}$, indicating that the protein ration was degraded to form sufficient $\mathrm{NH}_{3}$ for microbial growth. Part of the $\mathrm{NH}_{3}$ produced is absorbed, reused ( $\mathrm{N}$ recycling), and plays an important role in the metabolic process of ruminants [37]. Our results demonstrated that the $\mathrm{NH}_{3}$ concentration was not affected by the RDPR and NFC treatments. A similar result was also reported by Savari et al. [12]; however, these results differ from those of the previous studies, which showed that the $\mathrm{NH}_{3}$ concentration tended to increase as RDPR increases [6,32]. The insignificant effect of RDPR on $\mathrm{NH}_{3}$ concentration may be caused by the $\mathrm{C}$ chain balance released from NFC fermentation used for microbial synthesis. The insignificant difference in $\mathrm{NH}_{3}$ concentration may also result from the small RDPR levels used in this study [12].

VFAs are the primary energy source for ruminants. The total VFA concentration was not different between the treatments. This result was similar to those of Savari et al. [12] and Hall et al. [6], who found that total VFA concentration was not affected by RDPR nor NFC levels. The total VFA concentration in this study ranged from 100.96 to $121.20 \mathrm{mM}$, which is within the normal range for concentrate-forage-based rations [31]. Several factors can affect total VFA concentration, including the rate of rumen fermentation, the amount of soluble substrate, the rate of feed consumption, VFA absorption, and liquid or solid passage [38]. Nonetheless, in this study, the amount of fermented NFC and RDP did not significantly affect the total VFA concentration; this was due to the fermentation products of NFC and RDP being released in a balanced proportion and used by microbes for protein synthesis. In the rumen, VFAs are absorbed by rumen 
epithelial cells. Ruminal VFA absorption is influenced by the VFA production and absorption balance in the rumen, epithelial permeability to VFAs, and the blood transport of VFAs from epithelial cells [39].

Molar proportions of VFAs are affected by substrate composition, substrate availability, rate of depolymerization, and availability of rumen microbial species [40]. The interaction between NFC $(35 \%$ NFC and $40 \%$ NFC) with all levels of RDPR produced the highest molar proportion of acetate. Treatments NFC2 and NFC3 contained cassava meal at 20-30\% DM. Cassava meal is rich in carbohydrates, especially pectin, producing a high proportion of acetate [41]. This finding aligns with previous studies, which reported a high molar proportion of acetate in pectin-rich rations $[42,43]$.

Propionate is a substrate for gluconeogenesis, as the primary source of glucose in dairy cattle, whereas acetate and n-butyrate are sources of long-chain fatty acid synthesis [44]. In this study, the molar proportion of propionate was not affected by NFC nor RDPR. An insignificant effect of RDPR on the molar proportion of propionate has also been reported in several previous studies [35,45]. Conversely, Ma et al. [46] noted that the molar proportion of propionate increases as NFC increases; this different result is likely due to the use of different types of NFC. Nonetheless, other studies demonstrated that differences in the NFC content in rations play a small role in influencing rumen fermentation, especially propionate [47-49]. In addition, the molar proportion of n-butyrate decreased as the NFC level increased. A high level of NFC, rich in pectin content, is more fermentable than NFC rich in other forms of carbohydrates; this condition leads to higher acetate formation and lower formation of butyrate and lactate [50]. High molar proportions of butyrate are found in diets rich in saccharides, glucose, and disaccharides (fructose and sucrose) [6,20,51]. Butyrate plays a role in stimulating rumen papillae growth and proliferation [52].

Branched-chain VFAs (iso-butyrate, 2-methyl butyrate, and iso-valerate) are produced from oxidative deamination and decarboxylation of branched amino acids, such as valine, isoleucine, and leucine. Meanwhile, n-valerate is produced from carbohydrates and the carboxylic acid of proline, arginine, lysine, and methionine [53]. Iso-butyrate, iso-valerate, and n-valerate supply a $\mathrm{C}$ skeleton for the biosynthesis of branched-chain amino acids (valine, isoleucine, leucine, and proline) by cellulolytic bacteria [54]. This study found that the interaction between RDPR and NFC had a significant effect on the molar proportions of iso-butyrate and n-valerate; however, they did not affect iso-valerate. This result differed from a previous study, which reported no effect of the interaction between NFC and RDPR on iso-butyrate, n-valerate, and iso-valerate [46]. Moreover, Pormalekshahi et al. [45] reported that the molar proportion of iso-valerate and n-valerate were not affected by different levels of RDPR. Nonetheless, replacing the RDP source from true protein with NPN (non-protein N) decreases iso-butyrate [55].

The interaction between NFC and RDPR on the molar proportion of iso-butyrate and n-valerate may be because the combination of these two factors can supply the amino acids required for the formation of iso-butyrate and n-valerate. Iso-butyrate and n-valerate are the main components required for the growth of cellulolytic bacteria, especially Bacteroides succinogenes. Meanwhile, Ruminococcus flavefaciens requires iso-butyrate and iso-valerate, and $R$. albus requires iso-butyrate and 2-methyl butyrate [56]. The proportion of n-valerate was low in rations with high NFC levels (NFC2 and NFC3) for all RDPR levels; this may be caused by the treatment combinations' high pectin and low sugar contents. According to $\mathrm{Li}$ et al. [57], high molar n-valerate is produced from rations containing high concentrates and sugar.

The acetate to propionate ratio increases with increasing NFC levels. The high availability of readily fermentable carbohydrates increases the amount of cellulolytic bacteria, DM digestibility, and the acetate to propionate ratio [2]. Pectin is a component of the neutral detergent soluble fiber, and its fermentation results in a high acetate to propionate ratio and lower lactate levels, although it does not lower rumen $\mathrm{pH}$ [4]. A high availability of branched-chain VFAs (iso-butyrate, iso-valerate, and n-valerate) is required to grow cellulolytic bacteria [56]. Increasing cellulolytic bacteria activity increases acetate production, leading to increases of the acetate to propionate ratio $[58,59]$. The acetate propionate ratio is positively correlated with methane emissions $\left(\mathrm{CH}_{4}\right)$ from the fermentation process in the rumen and is used as an indicator of $\mathrm{CH}_{4}$ production [60]. The synthesis of acetate and butyrate produces hydrogen, whereas propionate synthesis uses hydrogen. Increasing the acetate and butyrate rumen concentration increases the hydrogen available for methanogenic bacteria to synthesize $\mathrm{CH}_{4}$ [61]. Estimations of $\mathrm{CH}_{4}$ based on VFA molar proportions influence the RDPR and NFC treatments, leading to high $\mathrm{CH}_{4}$ estimates in the NFC2, NFC3, and RDPR3 treatments.

\section{Rumen microbes and MPS}

The rumen microbes consist of bacteria, protozoa, and fungi. The rumen microbial population is influenced by the rumen $\mathrm{pH}$, temperature, buffer capacity, osmotic pressure, DM content, and oxidation-reduction potential [62]. Neither RDPR nor NFC affected the total bacteria and protozoa populations. The total bacteria population was 7.97-8.22 $\log \mathrm{CFU} / \mathrm{mL}$, lower than that recommended by McDonald et al. [30] for a normal rumen bacteria population in ruminants (9-10 $\log \mathrm{CFU} / \mathrm{mL}$ ). The lower total bacteria population in this study is likely due to the rations' low crude fiber content, required to achieve the high NFC levels in the ration formulation. Low bacteria populations (8.78-8.41 
$\log \mathrm{CFU} / \mathrm{mL}$ ) associated with high NFC treatments consisting of corn and DDGS concentrate have also been previously reported [63]. The mean protozoa population in this study was $6.55-6.62 \log$ cells $/ \mathrm{mL}$, within the normal range (5-6 log cells $/ \mathrm{mL}$ ) according to McDonald et al. [30]. An insignificant effect of carbohydrate type on the rumen protozoa population has also been previously reported [64]. In contrast, Vakili et al. [65] reported that NFC supplementation decreases the methanogenic bacteria and protozoa populations. Furthermore, they reported that the type of starch can reduce methanogenesis in the rumen.

Protozoa and rumen bacteria have different feeding behaviors with respect to protein digestion. Rumen bacteria are essential in degrading soluble protein, whereas protozoa degrade insoluble protein. In addition, as a predator, protozoa digest bacteria and fungi, and have a limited ability to assimilate peptides and amino acids [65]. Protozoa release more amino acids and peptides than bacteria in the rumen, but they cannot synthesize amino acids from ammonia [11]. According to Ferrand-Theix [66], protozoa defaunation increases $\mathrm{N}$ utilization by increasing the supply of amino acids to the small intestine and decreasing urinary $\mathrm{N}$ excretion into the environment. Factors that affect rumen protozoa include feed composition, rumen $\mathrm{pH}$, and feeding frequency [67].

Microbial protein is the primary protein source for ruminants. Approximately $80-90 \%$ of amino acid requirements are supplied by microbial protein with $80 \%$ digestibility $[11,68]$. MPS is influenced by the availability of energy from fermented carbohydrates in the rumen and $\mathrm{N}$ in the form of $\mathrm{NH}_{3}$ [11]. Both RDPR and NFC significantly affected MPS, but there was no interaction between the two factors. Treatment RDPR3 (RDPR of 60:40) produced higher MPS than RDPR1 and RDPR2, whereas treatment NFC2 (35\% NFC) produced higher MPS in comparison to NFC1 and NFC3. A previous study reported that an increase in RDP and rumen degradable starch increased recycled N, thereby increasing the supply of MPS to the small intestine and improving microbial protein efficiency [69]. High NFC in the rations may increase MPS since it provides quickly fermentable carbohydrates and energy [7].

In this study, MPS was $6.94-7.56 \mathrm{mg} / 10 \mathrm{~mL}$; this was lower than the range reported by Putri et al. [70], who reported a MPS of $10 \mathrm{mg} / 10 \mathrm{~mL}$ produced from a legume-based ration with $16 \%$ protein content and different RDPR levels $(55: 45,60: 40$, and 65:35). This difference in MPS is due to the difference in feed ingredients (leguminous vs. concentrate) and types of NFC used in the rations. Although the amino acids and NPN in the rations were not analyzed, we suggest that both components have a role in improving MPS. Changing RDP from true protein to NPN reduces MPS in lactating dairy cows [55], and in in vitro studies, feeding RDP as free amino acids and peptides promote microbial growth and efficiency [71]. The type of NFC also affects MPS. The high pectin and sugar types of NFC depressed MPS more than the starch type of NFC. The $\mathrm{N}$ efficiency for MPS varies, influenced by fermented carbohydrates' energy efficiency [72]. An average of $20 \mathrm{~g}$ of bacterial protein is synthesized per $100 \mathrm{~g}$ of organic matter fermented in the rumen [10]. The primary nutrients needed for MPS are carbohydrates and proteins. The balance of energy and N supply in MPS can be calculated by a synchronization index, which is calculated based on the organic matter and $\mathrm{N}$ degraded per hour [73]. A high synchronization index increases MPS [74]. In contrast, the low availability of essential micro minerals and vitamins become limiting factors for MPS production [2]. Therefore, supplementation of sulfur increases MPS efficiency [75].

\section{DMD and OMD}

The DMD and OMD values ranged from 61.46 to $76.22 \%$ and 60.09 to $75.12 \%$, respectively, indicating that the rations were moderately digestible. NFC provides easily digestible carbohydrates, including starch, simple sugars, beta-glucan, galactan, and pectin. Easily digestible carbohydrates provide energy and increase $\mathrm{N}$ utilization to synthesize microbial protein [76]. Rations with a higher energy supply produce higher DMD and OMD [7]. In this study, the highest DMD and OMD were noted with the NFC3 treatment ( $40 \%$ NFC), which used $30 \%$ of cassava in the ration as a source of NFC. The cassava cell wall is dominated by pectin substances, such as arabinans and xylogalacturonans [42]. According to Zhao et al. [8], DMD and OMD are higher under pectin treatments than starch and disaccharide-diet carbohydrates due to the rate of passage in the digestive tract [20]. In this study, the RDPR treatment did not affect DMD and OMD. The different degradability in the rumen was compensated by different post-ruminal digestibility, which resulted in similar total DMD and OMD. One previous study reported that an increasing RDPR level improves DMD and OMD [70]; this is true for rations high in fiber that rely mainly on rumen fiber degradation, but this was not the case in the current study.

\section{Conclusion}

Tropical dairy rations formulated using a combination RDPR of $60: 40$ with $35 \%$ NFC resulted in the best synchronization of available protein and energy for MPS and digestion activity in the rumen. Increasing NFC levels up to $40 \%$ resulted in higher DMD and OMD, but lower MPS. High NFC levels increased the acetate to propionate ratio suitable for milk fat synthesis. Further in vivo studies are needed to determine the effect of 60:40 RDPR and 35\% NFC on milk production and quality and the use of different NFC types in dairy rations, such as sugar, starch, and pectin.

\section{Authors' Contributions}

IGP and DD: Conceptualization, formulated the experimental design, revised and finalized the manuscript. AR: Experimental work at the laboratory, data 
analysis, and drafted the manuscript. All authors read and approved the final manuscript.

\section{Acknowledgments}

This study was funded by the Indonesian Ministry of Research and Technology-National Research and Innovation Agency within the Master Education Program, Leading to a Doctoral Program for Superior Bachelor (PMDSU) research scheme, contract No. 200/SP2H/PMDSU/DPRM/2020 and 077/SP2H/LT/DPRM/2021. The authors acknowledge the supporting staff from the Laboratory of Dairy Nutrition, Faculty of Animal Science, IPB University.

\section{Competing Interests} interests.

The authors declare that they have no competing

\section{Publisher's Note}

Veterinary World remains neutral with regard to jurisdictional claims in published institutional affiliation.

\section{References}

1. Dunlap, T.F., Kohn, R.A., Douglass, L.W. and Erdman, R.A. (2000) Diets deficient in rumen undegraded protein did not depress milk production. J. Dairy Sci., 83(8): 1806-1812.

2. Uddin, M.J., Khandaker, Z.H., Khan, M.J. and Khan, M.M.H. (2015) Dynamics of microbial protein synthesis in the rumen-a review. Ann. Vet. Anim. Sci., 2(5): 116-131.

3. Santos, S.A., de Carvalho, G.G.P., Azevêdo, J.A.G., Zanetti, D., Santos, E.M., Pereira, M.L.A., Pereira, E.S., Pires, A.J.V., de Campos Valadares Filho, S., de Almeida Teixeira, I.A.M., Tosto, M.S.L., Leite, L.C. and Mariz, L.D.S. (2021) Metabolizable protein: 1. Predicting equations to estimate microbial crude protein synthesis in small ruminants. Front. Vet. Sci., 8: 1-9.

4. Villalba, J.J., Ates, S. and MacAdam, J.W. (2021) Non-fiber carbohydrates in forages and their influence on beef production systems. Front. Sustain. Food Syst., 5: 1-12.

5. Mertens, D.R. (1997) Creating a system for meeting the fiber requirements of dairy cows. J. Dairy Sci., 80(7): 1463-1481.

6. Hall, M.B., Larson, C.C. and Wilcox, C.J. (2010) Carbohydrate source and protein degradability alter lactation, ruminal, and blood measures. J. Dairy Sci., 93(1): 311-322.

7. Zhou, X.Q., Zhang, Y.D., Zhao, M., Zhang, T., Zhu, D., $\mathrm{Bu}$, D.P. and Wang, J.Q. (2015) Effect of dietary energy source and level on nutrient digestibility, rumen microbial protein synthesis, and milk performance in lactating dairy cows. J. Dairy Sci., 98(10): 7209-7217.

8. Zhao, X.H., Gong, J.M., Zhou, S., Fu, C.B., Liu, C.J., Xu, L.J., Pan, K. and Qu, M.R. (2015) Effects of degradable protein and non-fibre carbohydrates on microbial growth and fermentation in the rumen simulating fermenter (Rusitec). Ital. J. Anim. Sci., 14(2): 220-225.

9. Dalley, D.E., Malcolm, B.J., Chakwizira, E. and de Ruiter, J.M. (2017) Range of quality characteristics of New Zealand forages and implications for reducing the nitrogen leaching risk from grazing dairy cows. New Zeal. J. Agric. Res., 60(3): 319-332.

10. Guliński, P., Salamończyk, E. and Młynek, K. (2016) Improving nitrogen use efficiency of dairy cows in relation to urea in milk-a review. Anim. Sci. Pap. Rep., 34(1): 5-24.

11. National Research Council. (2001) Nutrient Requirements of Dairy Cattle. $7^{\text {th }}$ ed. National Academy Press, Washington DC, USA.
12. Savari, M., Khorvash, M., Amanlou, H., Ghorbani, G.R., Ghasemi, E. and Mirzaei, M. (2018) Effects of rumen-degradable protein: Rumen-undegradable protein ratio and corn processing on production performance, nitrogen efficiency, and feeding behavior of Holstein dairy cows. $J$. Dairy Sci.,101(2): 1111-1122.

13. Kalscheur, K.F., Vi, R.L.B., Glenn, B.P. and Kohn, R.A. (2006) Milk production of dairy cows fed differing concentrations of rumen-degraded protein. J. Dairy Sci., 89(1): 249-259.

14. Kaufman, J.D., Kassube, K.R. and Ríus, A.G. (2017) Lowering rumen-degradable protein maintained energy-corrected milk yield and improved nitrogen-use efficiency in multiparous lactating dairy cows exposed to heat stress. J. Dairy Sci., 100(10): 1-14.

15. Bahrami-yekdangi, M., Ghorbani, G.R., Khorvash, M., Khan M.A. and Ghaffari, M.H.G. (2016) Reducing crude protein and rumen degradable protein with a constant concentration of rumen undegradable protein in the diet of dairy cows: Production performance, nutrient digestibility, nitrogen efficiency, and blood metabolites. J. Anim. Sci., 94(2): 718-725.

16. Svihus, B., Uhlen, A.K. and Harstad, O.M. (2005) Effect of starch granule structure, associated components and processing on nutritive value of cereal starch: A review. Anim. Feed Sci. Technol., 122(3-4): 303-320.

17. Gómez, L.M., Posada, S.L. and Olivera, M. (2016) Starch in ruminant diets: A review. Rev. Colomb. Ciencias. Pecu., 29(2): 77-90

18. Wei, Z., Zhang, B. and Liu, J. (2018) Effects of the dietary non-fiber carbohydrate content on lactation performance, rumen fermentation, and nitrogen utilization in mid-lactation dairy cows receiving corn stover. J. Anim. Sci. Biotechnol., 9(20): 1-7.

19. Martins, C.M.M., Fonseca, D.C.M., Alves, B.G., Arcari, M.A., Ferreira, G.C., Welter, K.C., Oliveira, C.A.F., Rennó, F.P. and Santos M.V. (2019) Effect of dietary crude protein degradability and corn processing on lactation performance and milk protein composition and stability. $J$. Dairy Sci., 102(5): 4165-4178.

20. Gao, X. and Oba, M. (2016) Effect of increasing dietary non-fiber carbohydrate with starch, sucrose, or lactose on rumen fermentation and productivity of lactating dairy cows. J. Dairy Sci., 99(1): 291-300.

21. Rosmalia, A., Permana, I.G., Despal, D. and Zahera, R. (2021) Estimation rumen degradable protein of local feeds in dairy cattle using in sacco method. In: IOP Conference Series: Earth and Environmental Science. P883.

22. Indah, A.S., Permana, I.G. and Despal, D. (2020). Determination of total digestible nutrient (TDN) of tropical forage using nutrient composition. Sains Peternak, 18(1): 38-43.

23. Tilley, J.M.A. and Terry, R.A. (1963) A two-stage technique for the in vitro digestion of forage crops. Grass Forage Sci., 18(2): 104-111.

24. Riestanti, L.U., Despal, D. and Retnani, Y. (2021) Supplementation of prill fat derived from palm oil on nutrient digestibility and dairy cow performance. Am. J. Anim. Vet. Sci., 16(2): 172-184.

25. Yulistiani, D., Puastuti, W., Haryanto, B., Purnomoadi, A., Kurihara, M. and Thalib, A. (2017) Complete rumen modifier supplementation in corn cob silage basal diet of lamb reduces methane emission. Indones. J. Agric. Sci., 18(1): 33 .

26. Moss, A.R., Jouany, J.P. and Newbold, J. (2000) Methane production by ruminants: Its contribution to global warming. Anim. Res., 49(3): 231-253.

27. Hu, W.L., Liu, J.X., Ye, J.A, Wu, Y.M. and Guo, Y.Q. (2005) Effect of tea saponin on rumen fermentation in vitro. Anim. Feed Sci. Technol., 120(3-4): 333-339.

28. Wahyudi, A., Cahyanto, M.N., Soejono, M. and Bachruddin, Z. (2010) Potency of lignocellulose degrading 
bacteria isolated from buffalo and horse gastrointestinal tract and elephant dung for feed fiber degradation. $J$. Indones. Trop. Anim. Agric., 35(1): 34-41.

29. Poulsen, M., Jensen, B.B. and Engberg, R.M. (2012) The effect of pectin, corn and wheat starch, inulin, and $\mathrm{pH}$ on in vitro production of methane, short-chain fatty acids and on the microbial community composition in rumen fluid. Anaerobe, 18(1): 83-90.

30. McDonald, P., Edwards, R.A., Greenhalgh, J.F.D., Morgan, C.A., Sinclair, L. and Wilkinson R.G. (2010) Animal Nutrition. $7^{\text {th }}$ ed. Pearson, London, UK.

31. Dieho, K., Dijkstra, J., Schonewille, J.T. and Bannink, A. (2016) Changes in ruminal volatile fatty acid production and absorption rate during the dry period and early lactation as affected by rate of increase of concentrate allowance. $J$. Dairy Sci., 99(7): 5370-5384.

32. Pilachai, R., Schonewille, J.T., Thamrongyoswittayakul, C., Aiumlamai, S., Wachirapakorn, C., Everts, H. and Hendriks, W.H. (2012) The effects of high levels of rumen degradable protein on rumen $\mathrm{pH}$ and histamine concentrations in dairy cows. J. Anim. Physiol. Anim. Nutr. (Berl.), 96(2): 20-213.

33. Erdman, R.A. (1988) Dietary buffering requirements of the lactating dairy cow: A review. J. Dairy Sci., 71(12): 3246-3266.

34. Firkins, J.L. (1996) Maximizing microbial protein synthesis in the rumen. In: Conference Altering Ruminal Nitrogen Metabolism to Improve Protein Utilization. p1347-1354.

35. Li, Q., Gao, Y., Cao, Y., Feng, Z. and Li, J. (2011) Effects of rumen-degradable protein balance on rumen fermentation in continuous culture fermenters. Front. Agric. China., 5(4): 598-604.

36. Gressley, T.F. and Armentano, L.E. (2007) Effects of low rumen-degradable protein or abomasal fructan infusion on diet digestibility and urinary nitrogen excretion in lactating dairy cows. J. Dairy Sci., 90(3): 1340-1353.

37. Liu, K., Li, Y., Luo, G., Xin, H., Zhang, Y. and Li, G. (2020) The relationships of dairy ruminal odd- and branched- chain fatty acids to the duodenal bacterial nitrogen flow and volatile fatty acids. Livest. Sci., 233(6): 103971.

38. Hall, M,B., Nennich, T.D., Doane, P.H. and Brink, G.E. (2015) Total volatile fatty acid concentrations are unreliable estimators of treatment effects on ruminal fermentation in vivo. J. Dairy Sci., 98(6): 3988-3999.

39. Storm, A.C., Kristensen, N.B. and Hanigan, M.D. (2012) A model of ruminal volatile fatty acid absorption kinetics and rumen epithelial blood flow in lactating Holstein cows. $J$. Dairy Sci., 95(6): 2919-2934.

40. Dijkstra, J. (1994) Production and absorption of volatile fatty acids in the rumen. Livest. Prod. Sci., 39(1): 61-69.

41. Staack, L., Della, P.E.A., Jørgensen, B., Pettersson, D. and Rangel, P.N. (2019) Cassava cell wall characterization and degradation by a multicomponent NSP-targeting enzyme (NSPase). Sci. Rep., 9(1): 1-11.

42. Ben-Ghedalia, D., Yosef, E., Miron, J. and Est, Y. (1989) The effects of starch- and pectin-rich diets on quantitative aspects of digestion in sheep. Anim. Feed Sci. Technol., 24(3-4): 289-298.

43. Zhao, X.H., Liu, C.J., Li, C.Y. and Yao, J.H. (2013) Effects of neutral detergent soluble fiber and sucrose supplementation on ruminal fermentation, microbial synthesis, and populations of ruminal cellulolytic bacteria using the rumen simulation technique (rusitec). J. Integr. Agric., 12(8): 1471-1480.

44. Morvay, Y., Bannink, A., France, J., Kebreab, E. and Dijkstra, J. (2011) Evaluation of models to predict the stoichiometry of volatile fatty acid profiles in rumen fluid of lactating Holstein cows. J. Dairy Sci., 94(6): 3063-3080.

45. Pormalekshahi, A., Fatahnia, F., Jafari, H., Azarfar, A., Varmaghany, S. and Taasoli, G. (2020) Interaction of dietary rumen undegradable protein level and supplemental rumen-protected conjugated linoleic acid on performance of growing goat kids. Small Rumin. Res., 191: 106167.

46. Ma, T., Tu, Y., Zhang, N.F., Deng, K.D. and Diao, Q.Y. (2015) Effect of the ratio of non-fibrous carbohydrates to neutral detergent fiber and protein structure on intake, digestibility, rumen fermentation, and nitrogen metabolism in lambs. Asian-Australasian J. Anim. Sci., 28(10): 1419-1426.

47. Brito, A.F., Broderick, G.A. and Reynal, S.M. (2007) Effects of different protein supplements on omasal nutrient flow and microbial protein synthesis in lactating dairy cows. J. Dairy Sci., 90(4): 1828-1841.

48. Broderick, G.A., Faciola, A.P. and Armentano, L.E. (2015) Replacing dietary soybean meal with canola meal improves production and efficiency of lactating dairy cows. J. Dairy Sci., 98(8): 5672-5687.

49. Paula, E.M., Monteiro, H.F., Silva, L.G., Benedeti, P.D.B., Daniel, J.L.P., Shenkoru, T., Broderick, G.A. and Faciola, A.P. (2017) Effects of replacing soybean meal with canola meal differing in rumen-undegradable protein content on ruminal fermentation and gas production kinetics using 2 in vitro systems. J. Dairy Sci., 100(7): 5281-5292.

50. Hindrichsen, I.K., Wettstein, H.R., Machmüller, A., Soliva, C.R., Bach, K.K.E., Madsen, J. and Kreuzer, M. (2004) Effects of feed carbohydrates with contrasting properties on rumen fermentation and methane release in vitro. Can. J. Anim. Sci., 84(2): 265-276.

51. Sutton, J.D. (1968) The fermentation of soluble carbohydrates in rumen contents of cows fed diets containing a large proportion of hay. Br. J. Nutr., 22(4): 689-712.

52. Mentschel, J., Leiser, R., Mülling, C., Pfarrer, C. and Claus, R. (2001) Butyric acid stimulates rumen mucosa development in the calf mainly by a reduction of apoptosis. Arch. Anim. Nutr. fur Tierernahrung., 55(2): 85-102.

53. Andries, J.I., Buysse, F.X., De Brabander, D.L. and Cottyn, B.G. (1987) Isoacids in ruminant nutrition: Their role in ruminal and intermediary metabolism and possible influences on performances-a review. Anim. Feed Sci. Technol., 18(3): 169-180.

54. Allison, M.J., Bryant, M.P. and Doetsch, R.N. (1962) Studies on the metabolic function of branched-chain volatile fatty acids, growth factors for ruminococci. I. Incorporation of isovalerate into leucine. J. Bacteriol., 83(5): 523-532.

55. Broderick, G.A. and Reynal, S.M. (2009) Effect of source of rumen-degraded protein on production and ruminal metabolism in lactating dairy cows. J. Dairy Sci., 92(6): 2822-2834.

56. Dehority, B.A., Scott, H.W. and Kowaluk, P. (1967) Volatile fatty acid requirements of cellulolytic rumen bacteria. $J$. Bacteriol., 94(3): 537-543.

57. Li, Y., He, M., Li, C., Forster, R., Beauchemin, K.A. and Yang, W. (2012) Effects of wheat dried distillers grains with solubles and cinnamaldehyde on in vitro fermentation and protein degradation using the Rusitec technique. Arch. Anim. Nutr., 66(2): 131-148.

58. Liu, Q., Wang, C., Huang, Y., Dong, K., Yang, W. and Wang, H. (2008) Effects of isobutyrate on rumen fermentation, urinary excretion of purine derivatives and digestibility in steers. Arch. Anim. Nutr., 62(5): 377-388.

59. Liu, Q., Wang, C., Guo, G., Huo, W.J., Zhang, Y.L., Pei, C.X., Zhang, S.L. and Wang, H. (2018) Effects of branched-chain volatile fatty acids supplementation on growth performance, ruminal fermentation, nutrient digestibility, hepatic lipid content and gene expression of dairy calves. Anim. Feed Sci. Technol., 237(1): 27-34.

60. Mohammed, R., McGinn, S.M. and Beauchemin, K.A. (2011) Prediction of enteric methane output from milk fatty acid concentrations and rumen fermentation parameters in dairy cows fed sunflower, flax, or canola seeds. J. Dairy Sci., 94(12): 6057-6068.

61. Lyons, T., Bielak, A., Doyle, E. and Kuhla, B. (2018) Variations in methane yield and microbial community profiles in the rumen of dairy cows as they pass through stages 
of first lactation. J. Dairy Sci., 101(6): 5102-5114.

62. Castillo-González, A.R., Burrola-Barraza, M.E., Domínguez-Viveros, J. and Chávez-Martínez, A. (2014) Rumen microorganisms and fermentation. Arch. Med. Vet., 46(1): 349-361.

63. Wu, H., Meng, Q. and Yu, Z. (2015) Effect of pH buffering capacity and sources of dietary sulfur on rumen fermentation, sulfide production, methane production, sulfate reducing bacteria, and total Archaea in in vitro rumen cultures. Bioresour. Technol., 186(1): 25-33.

64. Firkins, J.L., Yu, Z. and Morrison, M. (2007) Ruminal nitrogen metabolism: Perspectives for integration of microbiology and nutrition for dairy. J. Dairy Sci., 90(1): E1-E16.

65. Hino, T. and Russell, J.B. (1987) Relative contributions of ruminal bacteria and protozoa to the degradation of protein in vitro. J. Anim. Sci., 64(1): 261-270.

66. Ferrand-theix, C. (1996) Effect of rumen protozoa on nitrogen utilization by ruminants. In: Conference Altering Ruminal Nitrogen Metabolism to Improve Protein Utilization. p1335-1346.

67. Franzolin, R. and Dehority, B.A. (1996) Effect of prolonged high-concentrate feeding on ruminal protozoa concentrations. J. Anim. Sci., 74(11): 2803-2809.

68. Russell, J.B., Muck, R.E. and Weimer, P.J. (2009) Quantitative analysis of cellulose degradation and growth of cellulolytic bacteria in the rumen. FEMS Microbiol. Ecol., 67(2): 183-197.

69. Davies, K.L., McKinnon, J.J. and Mutsvangwa, T. (2013) Effects of dietary ruminally degradable starch and ruminally degradable protein levels on urea recycling, microbial protein production, nitrogen balance, and duodenal nutrient flow in beef heifers fed low crude protein diets. Can. J. Anim. Sci., 93(1): 123-136.

70. Putri, E.M., Zain, M., Warly, L. and Hermon, H. (2021) Effects of rumen-degradable-to-undegradable protein ratio in ruminant diet on in vitro digestibility, rumen fermentation, and microbial protein synthesis. Vet. World, 14(3): 640-648.

71. Atasoglu, C., Valdés, C., Newbold, C.J. and Wallace, R.J. (1999) Influence of peptides and amino acids on fermentation rate and de novo synthesis of amino acids by mixed micro-organisms from the sheep rumen. Br. J. Nutr., 81(4): 307-314.

72. Bach, A., Calsamiglia, S. and Stern, M.D. (2005) Nitrogen metabolism in the rumen. J. Dairy Sci., 88(1): E9-E21.

73. Sinclair, L.A., Garnsworthy, P., Newbold, J.R. and Buttery, P.J. (1993) Effect of synchronizing the rate of dietary energy and nitrogen release on rumen fermentation and microbial protein synthesis in sheep. J. Agric. Sci., 120(2): 251-263.

74. Kaswari, T., Lebzien, P., Flachowsky, G. and ter Meulen, U. (2007) Studies on the relationship between the synchronization index and the microbial protein synthesis in the rumen of dairy cows. Anim. Feed Sci. Technol., 139(1): 1-22.

75. Bal, M.A. and Ozturk, D. (2006) Effects of sulfur containing supplements on ruminal fermentation and microbial protein synthesis. Res. J. Anim. Vet. Sci., 1(1): 33-36.

76. Cherney, D.J.R., Cherney, J.H. and Chase, L.E. (2003) Influence of dietary non-fiber carbohydrate concentration and supplementation of sucrose on lactation performance of cows fed fescue silage. J. Dairy Sci., 86(12): 3983-3991. 